\title{
Nigerian Mushrooms: Underutilized Non-Wood Forest Resources \\ ${ }^{1}$ OKHUOYA, J.A.; ${ }^{1}$ AKPAJA, E.O.; *11OSEMWEGIE, O.O.; ${ }^{1}$ OGHENEKARO, A.O.; ${ }^{2}$ IHAYERE, C. A.
}

\author{
${ }^{1}$ University of Benin, Faculty of Life Sciences, Department of Plant Biology and Biotechnology, P.M.B 1154, Benin City, Edo State, \\ Nigeria. ${ }^{2}$ Western Delta University, Department of Biological Sciences and Biotechnology, P.M.B 10, Oghara, Delta State, Nigeria. \\ *Corresponding author: Email address: omorefo@yahoo.com. Phone number: +2348028383027.
}

\begin{abstract}
Mushroom resources have been exploited in most developed economies because of their huge agro-industrial, medicinal and commercial benefits. Nigerians utilized mushroom-forming fungi only for food and folk medicine for many decades. Auricularia auricular Judae (Bull.) Quél, Lentinus squarrosulus Mont., Pleurotus tuberregium (Fr.) Singer and Volvariella volvacea (Bull.) Singer was some of the common edible mushrooms that were successfully cultivated in Nigeria on small-scale basis. The mushroom resources in Nigeria are grossly under-studied and their attractive potentials under-exploited for addressing economic and industrial development. Resourceful biotechnological approach in the application of mushrooms in agriculture, medicine, industry and environment is inchoate and uncommon in the country. @ JASEM
\end{abstract}

Mushrooms are widespread in nature and they remained the earliest form of fungi known to mankind. In Nigeria, many people in both urban and rural areas are familiar with mushroomforming fungi growing around them some of which they exploit for food and medicine. This practice although reported all-over the country is more pronounce amongst the Yoruba speaking people (Alabi, 1991). Concomitant varieties of mushrooms i.e. lichenized, mycorrhizal, parasitic and saprotrophic that abound in Nigeria have continued to gain recognition and elicit different interests and questions as potentially resourceful tool in economic modulation pari passu prevailing reliance on leafy plants. It is saddening to see that people from all works of life associate mushrooms with negative events in Nigeria and most African countries (Yongabi et al., 2004; Akpaja et al., 2005). This image, in addition to the slow development of mushroom cultivation practices is changing due to reports elsewhere in the world that illuminate potentials of mushroom-forming fungi and mushroom products and their uses in different spheres of human welfare (Wainwright, 1992; Robert and Hajek, 1993; Wasser, 2007). This is apart from their hitherto pivotal roles in sustaining eco-energy balance in nature (Jumpponen et al., 2004).

In Africa, mushroom resource exploration and exploitation is fraught with lack of infrastructure and technical supports from national and international agencies, scarcity of mushroom scientists, poor political and legislative support, poor knowledge of mushroom biodiversity due to dearth of mushroom taxonomists and bad press reports amongst others (Laberere and Menini, 2000). Reports on Nigerian mushrooms such as Ogundana (1975), Oso (1975 and 1977) and Zoberi (1973) are old and currently an underrepresentation of Nigerian mushroom's diversity, composition and uses. African nations are seldom listed among the largest producers and exporters of edible mushrooms and mushroom products (Chang and Miles, 1991; Flegg, 1992).

The objective of this paper therefore, is to review the mushroom research-application divides in Nigeria against the flux of unprecedented global reports on mushroom potentials, explorations and exploitations for human benefits. This illuminated the need to prospect mushrooms and shift focus from reliance on plant genetic resources to mycotas as btter alternative in addressing Nigeria's economic and technological development by reviewing existing mushroom articles on Nigeria.

Mycophagy: A good number of mushrooms have been reported by Akpaja et al., (2003, 2005), Osemwegie et al. (2006), Gbolagade et al. (2006) to be consumed by different tribal groups in Nigeria. People depending on their tribe slightly differ in the array of mushrooms consumed and reasons for their consumption (Oso, 1975). The Yoruba tribes however recorded the highest number of edible and medicinal mushrooms compared to the Hausa tribes (Table 1). The reason for this trend is not fully understood but it is believed to be connected to the relatively few accounts of edible, medicinal and cultivable mushrooms in extant literature. Factors such as the arid nature of the North occasioned by desert encroachment; scarcity of mushroom biologists and mushroom interest; availability of alternative protein sources may have contributed to the scarcity of mushroom information on the Hausas (Idu et al., 2007). Many culturally varied mycophagists are ignorant of the nutritional values of edible mushrooms but consume them based on their organoleptic property such as aroma, taste, flavour, and texture (Ene-Obong and Camovale, 1992; Osemwegie et al., 2006). Other reasons reported for mycophagy in Nigeria are subsumed in their local names e.g. Volvariella volvacea (Bull.) Singer is referred to by the Yoruba people as "ogiri agbe" meaning farmer's spice (Oso, 1975) while Lentinus sp is called "Ero atakata" by the Igbo 
speaking people, a name derived from its tough texture (Akpaja et al, 2003). Studies on the nutritional values of edible and medicinal mushrooms ranked them with dairy, plant and animal food in vitamins, protein and mineral contents. This has however failed to neither improve mycophagy culture in urban cities in Nigeria nor promote the commercial productions of mushrooms (Ene-Obong and Camovale, 1992; Adewusi et al., 1993; Aletor, 1995). The most popular edible mushroom in Nigeria is the sclerotium-forming Pleurotus tuberregium (Fr.) Singer which is eaten as food and/or used as food supplement (Gbolagade et al., 2006). The sporophore is used as a good substitute for meat protein in several suburban Nigerian soups by locals (Ene-Obong and Camovale, 1992). Its popularity as food in many rural villages especially in the south zone of the country is ascribed to its substrate propensity, rapid growth, fruit-body longevity, incidences and distribution pattern (Zoberi, 1973; Osemwegie et al., 2006). Other edible mushrooms consumed in Nigeria include Agaricus spp., Auricularia auricular Judae (Bull.) Quél., Collybia butyracea (Bull.) P. Kumm., Coprinus atramentarius (Bull.) Fr., Coprinus picaceus (Bull.) Gray, Lactarius trivialis Fr., Lentinus squarrosulus Mont., Pleurotus pulmonarius(Fr.) Quél., Pleurotus ostreatus Jacq., Macrolepiota sp., Psathyrella atroumbonata Pegler, Schizophyllum commune Fr., Termitomyces clypeatus Heim., Termitomyces globules Heim \& Gooss, Termitomyces mammiformis Heim., Termitomyces microcarpus (Berk. \& Br.) Heim, Termitomyces robustus (Beeli.) Heim, Tricholoma sp., Volvariella volvacea (Bull.) Singer and Volvariella esculenta (Mass.) Singer (Fig. 2 and Table 1). Amanita mushrooms which were labeled poisonous in many parts of the world have been reported in Nigeria by Zoberi (1973) and elsewhere in Africa (Morris, 1990) to have species that are consumed as food. In the same vein, Chlorophyllum molybditis also featured amongst edible mushrooms analyzed for their nutrient contents in Nigerian and considered safe for consumption (Fasidi and Kadiri, 1995; Aletor and Aladetimi, 1995). The edibility Amanita and Chlorophyllum species earlier reported as poisonous elsewhere in the world by Nigerians is not totally understood but it is believed that the controversy may stem from any one or combination of factors relating to environment, genetic and physiological differences which were determinants of tolerance level to toxins amongst racially, geographically and traditional varied people. The method of preparation of these mushrooms, insufficient expert taxonomist and/or poor identification method coupled with the use of monographic/taxonomic books on western mushroom taxa for naming indigenous African macrofungi may also have been responsible for this contention (Osemwegie and Okhuoya, 2009).
Regular and professional myco-systematic molecular-based approach coupled with frequent revised documentations of mushroom-forming fungi may resolve further the confusions associated with edible and poisonous mushrooms.

In Nigeria, a great quantity and variety of edible and medicinal mushrooms are sourced from the wild due to inchoate mushroom farming culture. This practice (mushroom scouting/hunting) existed for decades spanning generations and mostly embarked upon by children and women (Okhuoya, 1997). About twenty-five edible mushroom species of good repute whose knowledge were handed down generational lines via oral communication have been identified in Nigeria (Labarere and Menini, 2000). Osemwegie et al. (2006) stated that edible mushrooms collected from various farmlands, forests and plantations may be sold or cooked fresh, after treatment with warm salt water, with the addition of essential ingredients like pulped pepper, tomatoes, onions, salt and oil or smoked and/or sun-dried for later use. The reliance on naturally growing edible mushrooms has greatly undermined the development of mushroom cultivation to a commercial scale despite available substrate materials in some African nations. Some of the substrate materials of diverse origin tested in the artificial cultivation of mushrooms in Nigeria are outlined in (Table 3). Despite the fact that about $20 \%$ of the world's population was reported by Labarere and Menini (2000) as starving, African nations are still lacking amongst the mushroom exporting nations of the world. Tapping into the benefits of commercial mushroom production in Nigeria will reduce the country's unemployment rate, increase her food security and revenue base while bridging her rural-urban mycophagy gap.

The number of cultivable edible mushrooms worldwide amounts to over a hundred with an annual production of over 4.5 million tons and still increasing (Flegg, 1992; Laberere and Menini, 2000; Mshigeni, 2005). The provision of safe sustainable access to edible and medicinal mushrooms in Nigeria can be achieved in a number of ways which may include (i) by promoting opportunities for co-operation between all stakeholders such as the mushroom farmers, researchers/mycologists, politicians and other mushroom prospectors (marketer, NGOs and government agencies on agriculture, youths and women etc.) in the country; (ii) through the creation of public enlightenment initiatives via talk shows on the positive potentials of mushrooms and mushroom products in radio and television programs, monthly newsletter, seminars and workshops. This will remove the negative publicity associated with mushrooms, increase market sources of edible mushrooms, limit the dangers associated with mushroom hunting from the wild and improve awareness on both the nutrient quality and benefits of mushroom consumption; (iii) by developing a model that allows for spawn 
availability to farmers and steady flow and/or exchange of proprietary culture (mother cultures and pure-lines). This is in addition to the crossfertilization of cultivation technologies between developing and industrial nations, and creation of recognized indigenous mushroom growers association. The establishment of sustainable regional mushroom germplasm banks and research centers to maintain mushroom genetic stability, quality control of mushroom culture collections and spawn, and preservation of cultures of extant and extinct mycoresources can also enhance the overall uses of mushrooms in the country. One cannot but add that the elevation of mushrooms to a cash-crop status in Nigeria requires improved political will and solid infrastructural (steady electricity, flowing water, buildings etc.) setting. These will have unprecedented impact on the development of the country's mushroom industries in providing food, drugs and chemicals. It will equally offer opportunity for conservation strategies and preservation of mushrooms that will add value to medicine, pharmacy, industries and agriculture.
Despite the high level of progress made through the Global Network on Mushroom Research and Development under the aegis of F.A.O and the advancement of mushroom cultivation industries in many developed nations, growing mushrooms in homes or even on a commercial scale is still uncommon in Nigeria. Researchers are therefore challenged to reduce dependence on naturally occurring mushrooms, the incidences of mushroom poisoning and expand the nation's edible and medicinal mushroom base. Many indigenous edible mushrooms heritage and knowledge may have escaped recognition and documentation and/or completely lost over the years. Although, few works such as such as Akpaja et al. (2003, 2005), Okhuoya and Akpaja (2005) and Osemwegie et al. (2006), a long-term study on the ethnomycological, taxonomic and myco-diversity profile of indigenous mushroom resources on a national scale will form the inertia for mushroom prospecting initiatives and successful exploitation in developmental economic issues in Nigeria. Some of the wild mushrooms occurring in Nigeria are presented in Fig. 2.

Table 1: Summary of some edible and medicinal mushrooms and their distribution in Nigeria.

\begin{tabular}{|c|c|c|c|}
\hline Mushroom & Yoruba(West) & Igbo (East) & Hausa (North) \\
\hline Auricularia auricular Judae (Bull.) Quél. & + & + & + \\
\hline Calvatia cyathiformis (Bosc.) Morg. & + & - & + \\
\hline Chlorophyllum molybditis (Mayer ex. Fr.) Massee & $*$ & + & - \\
\hline Coprinus picaceus (Bull. ex Fr.) S.F.Gray & - & + & - \\
\hline Coprinus setulosus Berk. and $\mathrm{Br}$. & + & - & - \\
\hline Coprinus tramentarius Ulje and Bas. & + & - & - \\
\hline Cortiarius melliolens Fries & + & + & $*$ \\
\hline Daldinia concentrica (Bolt. ex Fr.) Ces. and DeNot. & $*$ & * & * \\
\hline Lentinus subnudus Berk & $+*$ & + & - \\
\hline Pleurotus ostreatus Jacq. & $+*$ & + & \\
\hline Pleurotus pulmonarius (Fr.) Quél & + & - & - \\
\hline Pleurotus squarrosulus (Mont.) Singer & + & $+*$ & + \\
\hline Pleurotus tuberregium (Fr.) Singer & $+*$ & $+*$ & $+*$ \\
\hline Psathrella atroumbonata Pegler & + & + & - \\
\hline Schizophylum commune Fr. & $+*$ & + & $*$ \\
\hline Termitomyces clypeatus Heim & + & + & + \\
\hline Termitomyces globules Heim and Gooss & + & + & - \\
\hline Termitomyces microcarpus (Berk. and Br.) Heim & - & + & - \\
\hline Termitomyces robustus (Beeli) Heim & + & + & + \\
\hline Volvariella esculenta (Mass) Singer & + & + & - \\
\hline Volvariella volvacea (Bull.) Singer & + & - & - \\
\hline
\end{tabular}

* Corresponding author: *Osemwegie, O.O. 
Table 2: Some substrates used for cultivation of edible and medicinal mushrooms in Nigeria.

\begin{tabular}{|c|c|c|c|}
\hline Wastes & Origin/Source & hroom & Reference \\
\hline \multicolumn{4}{|l|}{ Farm wastes: } \\
\hline Rice straw/husk & Rice farms & $\begin{array}{l}\text { Pleurotus ostreatus Jacq., } \\
\text { P. tuberregium (Fr.) } \\
\text { Singer, Volvariella } \\
\text { volvacea (Bull.) Singer. }\end{array}$ & $\begin{array}{l}\text { Okhuoya (1997), Ibekwe et al. } \\
\text { (2008), Ukoima et al. (2009) }\end{array}$ \\
\hline Wheat straw/bran & Wheat farms & 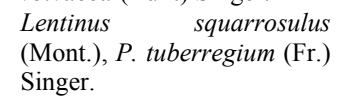 & $\begin{array}{l}\text { Okhuoya (1997), Gbolagade } \\
\text { (2006) }\end{array}$ \\
\hline $\begin{array}{l}\text { Corn straw, bracts } \\
\text { and cobs }\end{array}$ & $\begin{array}{l}\text { Corn farms, roasted and } \\
\text { boiled corn retailers, palp } \\
\text { (locally called ogi or akamu) } \\
\text { maker. }\end{array}$ & $\begin{array}{l}\text { P. tuberregium (Fr.) } \\
\text { Singer, Psathyrella } \\
\text { atroumbonata Pegler. }\end{array}$ & $\begin{array}{l}\text { Okhuoya (1997), Ayodele and } \\
\text { Okhuoya (2007) }\end{array}$ \\
\hline Cassava peelings & Cassava mills/suburbs & P. pulmonarius (Fr.) Quél. & Onuoha et al.(2009) \\
\hline $\begin{array}{l}\text { Plantain/banana leaves, } \\
\text { peelings and pseudo } \\
\text { stems }\end{array}$ & Farms, roasted plantain retailers & P. tuberregium (Fr.) Singer & Osemwegie el al. (2002) \\
\hline Cocoa pod & $\begin{array}{l}\text { Farms, local cocoa } \\
\text { processing industries }\end{array}$ & P. ostreatus Jacq. & Alemawor et al. (2009) \\
\hline Coconut fruit fibre & Farms, industries & $\begin{array}{l}\text { Lentinus subnudus Berk, } P \text {. } \\
\text { tuberregium (Fr.) Singer, } V \text {. } \\
\text { volvacea (Bull.) Singer. }\end{array}$ & $\begin{array}{l}\text { Okhuoya and Okogbo, (1991), } \\
\text { Fasidi and Kadiri (1993), Fasola } \\
\text { et al. (2007) }\end{array}$ \\
\hline \multicolumn{4}{|l|}{ Industrial wastes: } \\
\hline Cotton wastes & Textile mills & P. pulmonarius (Fr.) Quél & Adebayo et al. (2009) \\
\hline Sawdust & Saw mills & $\begin{array}{l}\text { Psathrella atroumbonata } \\
\text { Pegler, P. tuberregium (Fr.) } \\
\text { Singer. }\end{array}$ & $\begin{array}{l}\text { Ayodele and Okhuoya (2007), } \\
\text { Okhuoya et al. (1998) }\end{array}$ \\
\hline $\begin{array}{l}\text { Oil palm fruit fibre } \\
\text { and cake }\end{array}$ & Oil palm mills & $\begin{array}{l}\text { P. pulmonarius (Fr.) Quél, } \\
\text { Psathrella atroumbonata } \\
\text { Pegler. }\end{array}$ & $\begin{array}{l}\text { Ayodele and Okhuoya (2007), } \\
\text { Onuoha et al.(2009) }\end{array}$ \\
\hline \multicolumn{4}{|l|}{ Domestic wastes: } \\
\hline Waste papers & $\begin{array}{l}\text { Paper mills, printing factory, } \\
\text { surrounding. }\end{array}$ & P. tuberregium (Fr.) Singer. & Osemwegie el al. (2002) \\
\hline
\end{tabular}

Table 3: Some edible and medicinal mushrooms in Nigeria analyzed for toxins, secondary metabolites and other nutritional contents.

\begin{tabular}{|c|c|c|c|c|}
\hline Mushroom & $\begin{array}{l}\text { nutritional } \\
\text { content }\end{array}$ & Toxin & $\begin{array}{l}\text { Secondary } \\
\text { metabolites }\end{array}$ & References \\
\hline Auricularia auricular Judae (Bull.) Quél. & + & - & - & $\begin{array}{l}\text { Aletor (1995), Aletor and Aladetimi } \\
\text { (1995) }\end{array}$ \\
\hline Calvatia cyathiformis (Bosc.) Morg. & + & - & - & Aletor (1995) \\
\hline Chlorophyllum molybditis (Mayer ex. Fr.) Massee & - & + & + & $\begin{array}{l}\text { Fasidi \& Kadiri (1995), Kadiri \& Fasidi } \\
\text { (1992) }\end{array}$ \\
\hline Cortinarius melliolens Fr. & - & + & + & $\begin{array}{l}\text { Kadiri \& Fasidi (1992), Fasidi \& Kadiri } \\
\text { (1995) }\end{array}$ \\
\hline Lentinus subnudus Berk. & + & + & - & $\begin{array}{l}\text { Kadiri \& Fasidi (1992), Aletor (1995), } \\
\text { Fasidi \& Kadiri (1995), }\end{array}$ \\
\hline Lactarius trivialis Fr. & + & - & - & Adejumo \& Awosanya (2005) \\
\hline Pleurotus tuberregium (Fr.) Singer & - & + & + & $\begin{array}{l}\text { Kadiri \& Fasidi (1992), Fasidi \& Kadiri } \\
\text { (1995), Adejumo \& Awosanya (2005) }\end{array}$ \\
\hline Psathyrella atroumbonata Pegler & + & - & - & Aletor (1995) \\
\hline Schizophylum commune Fr. & + & - & - & Aletor (1995) \\
\hline Termitomyces microcarpus (Berk. and Br.) Heim & + & - & - & Aletor (1995) \\
\hline Termitomyces robustus (Beeli) Heim & + & + & + & $\begin{array}{l}\text { Kadiri \& Fasidi (1992), Aletor (1995), } \\
\text { Fasidi \& Kadiri (1995) }\end{array}$ \\
\hline Tricholoma lobayense Heim & - & + & - & $\begin{array}{l}\text { Kadiri \& Fasidi (1992), Fasidi \& Kadiri } \\
\text { (1995) }\end{array}$ \\
\hline Volvariella esculenta (Mass) Singer & - & + & + & $\begin{array}{l}\text { Kadiri \& Fasidi (1992), Fasidi \& Kadiri } \\
\text { (1995) }\end{array}$ \\
\hline
\end{tabular}


Table 4: Antagonistic potentials of some Nigerian mushrooms against some pathogens.

Auricularia polytricha

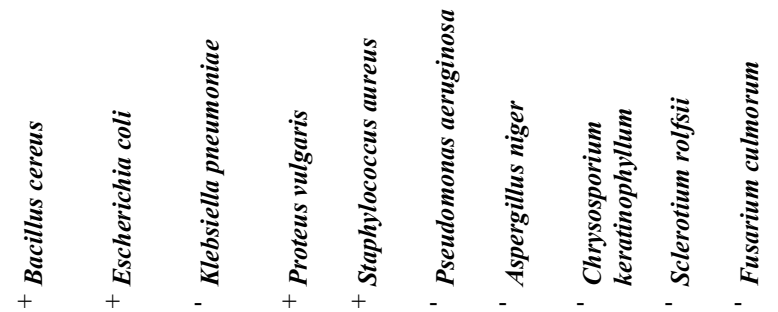
(Mont.) Sacc.

\begin{tabular}{|c|c|c|c|c|c|c|c|c|c|c|c|}
\hline $\begin{array}{l}\text { Auricularia polytricha } \\
\text { (Mont.) Sacc. }\end{array}$ & 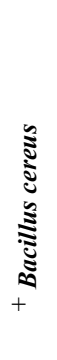 & 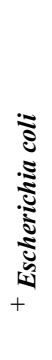 & 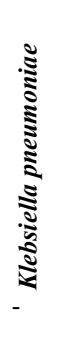 & 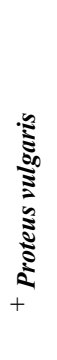 & 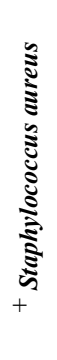 & 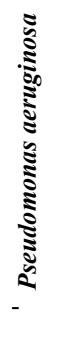 & 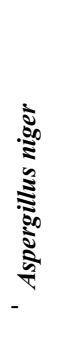 & 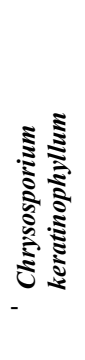 & 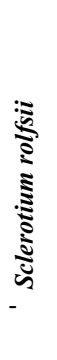 & 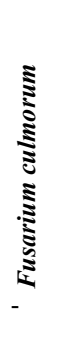 & Gbolagade and Fasidi (2005) \\
\hline $\begin{array}{l}\text { Coriolopsis } \\
\text { occidentalis (Klotzsch) } \\
\text { Murr. }\end{array}$ & + & + & + & + & + & - & + & - & - & - & Gbolagade and Fasidi (2005) \\
\hline $\begin{array}{l}\text { Daedalea elegans } \\
\text { Spreng. }\end{array}$ & + & + & + & + & + & - & - & - & - & - & Gbolagade and Fasidi (2005) \\
\hline $\begin{array}{l}\text { Daldinia concentrica } \\
\text { (Bolt.) Ces. \& De Not. }\end{array}$ & + & + & + & + & + & - & - & - & - & - & Gbolagade and Fasidi (2005) \\
\hline $\begin{array}{l}\text { Fomes lignosus } \\
\text { (Klotzsch) Bres. }\end{array}$ & + & + & - & + & + & - & - & - & - & - & Gbolagade et al.(2007) \\
\hline $\begin{array}{l}\text { Marasmius jodocodo } \\
\text { Henn. }\end{array}$ & + & - & + & + & + & - & + & - & - & - & Gbolagade et al.(2007) \\
\hline $\begin{array}{l}\text { Pleurotus tuberregium } \\
\text { (Fr.) Sing. }\end{array}$ & + & + & + & + & + & + & - & + & + & + & $\begin{array}{l}\text { Okhuoya et al. (1996), } \\
\text { Gbolagade et al.(2007), } \\
\text { Badalyan et al. (2008) }\end{array}$ \\
\hline $\begin{array}{l}\text { Polyporus giganteus } \\
\text { (Pers.) Fr. }\end{array}$ & + & + & + & - & - & - & + & - & - & - & Gbolagade et al.(2007) \\
\hline $\begin{array}{l}\text { Psathyrella } \\
\text { atroumbonata Pegler }\end{array}$ & + & + & + & + & + & - & + & - & - & - & Gbolagade et al.(2007) \\
\hline $\begin{array}{l}\text { Termitomyces } \\
\text { microcarpus } \\
\text { and Br.) Heim }\end{array}$ & - & + & - & + & + & - & - & - & - & - & Gbolagade et al.(2007) \\
\hline $\begin{array}{l}\text { Termitomyces robustus } \\
\text { (Beeli) Heim }\end{array}$ & + & + & + & - & + & - & + & - & - & - & Gbolagade et al.(2007) \\
\hline $\begin{array}{l}\text { Tricholoma lobayense } \\
\text { Heim }\end{array}$ & + & + & + & + & + & - & - & - & - & - & Gbolagade and Fasidi (2005) \\
\hline
\end{tabular}




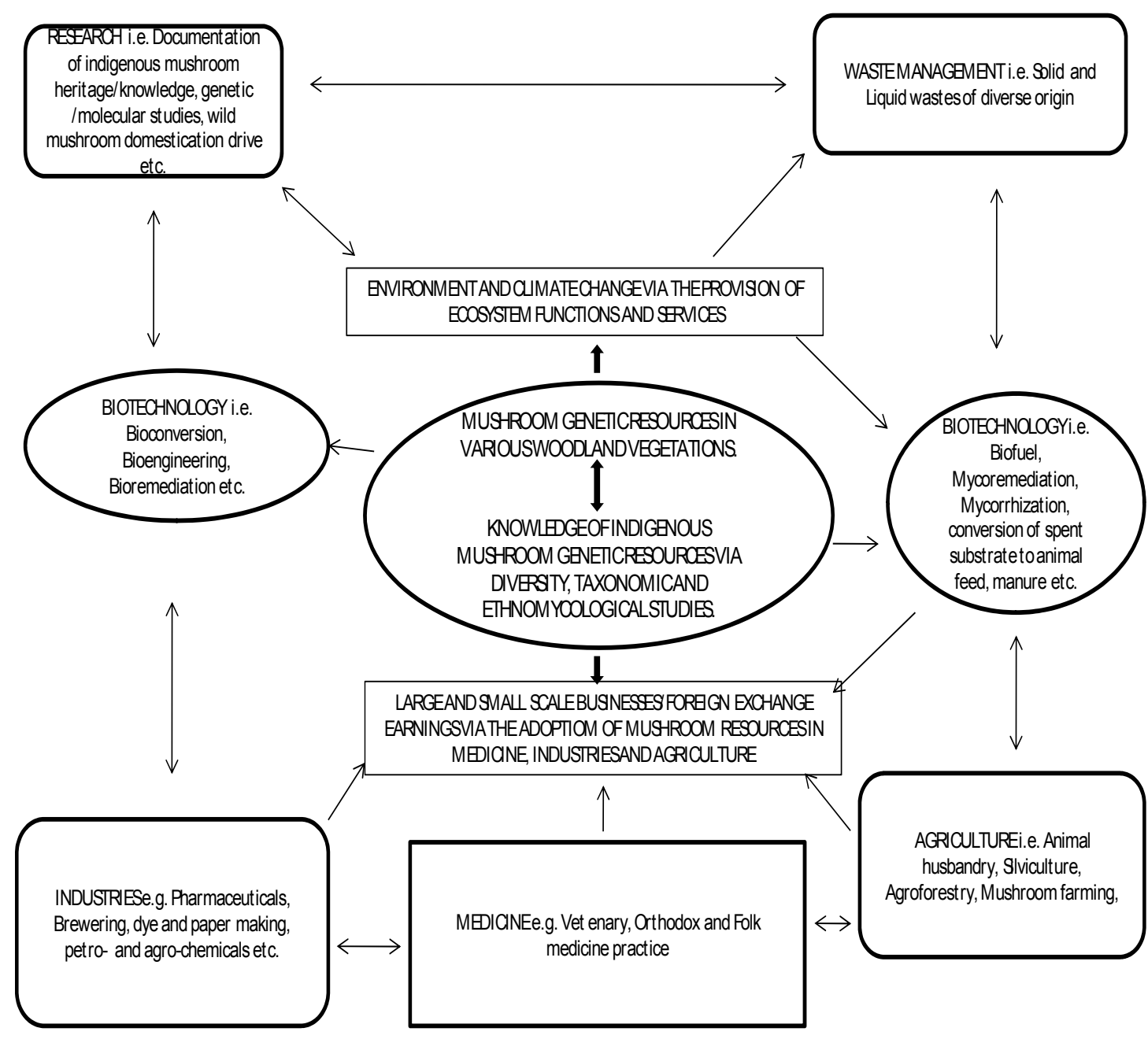

Figure 1: A model showing mushroom genetic resource utilization flow and potentials 


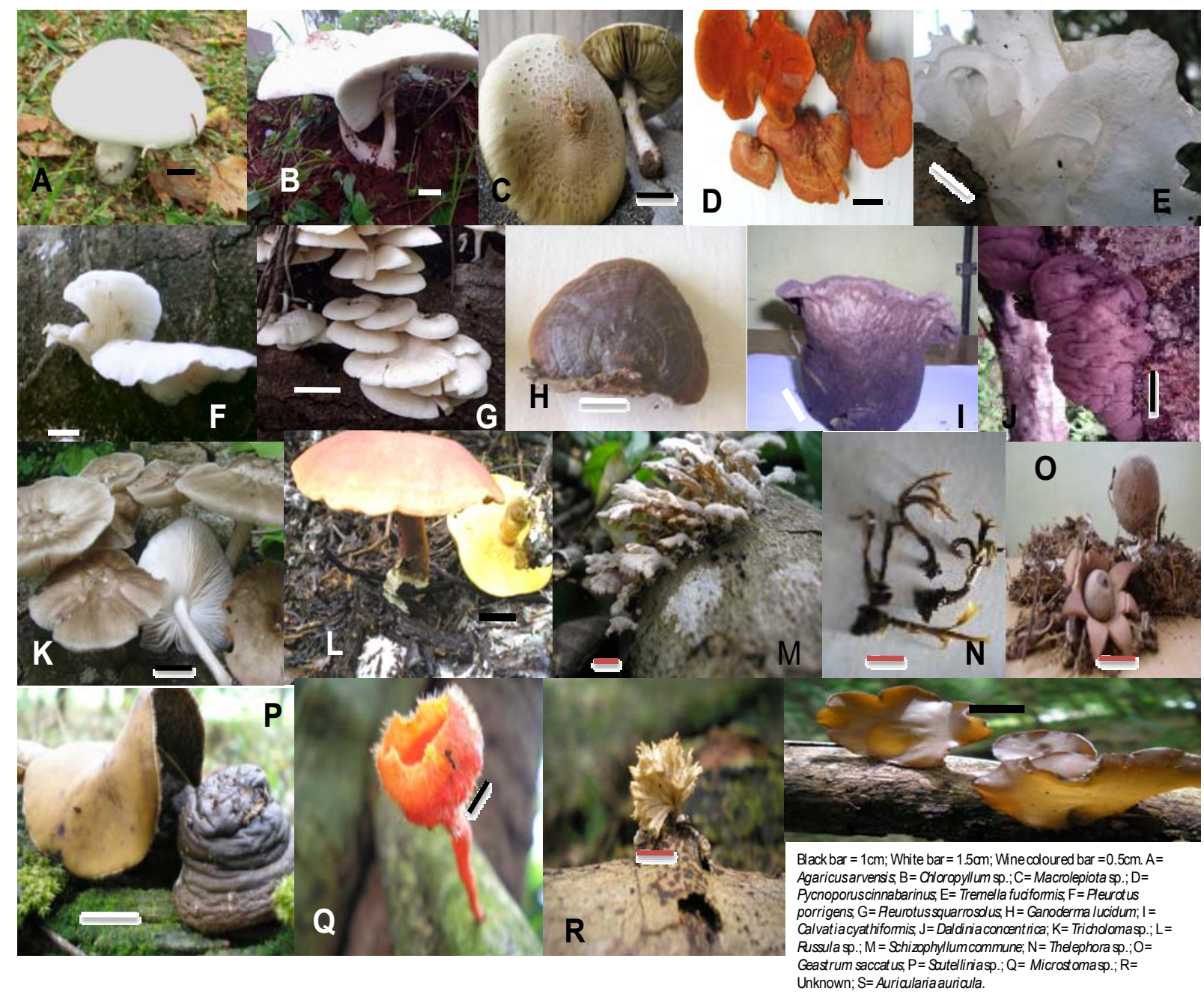

Figure 2: Some exotic, medicinal, edible and economically valuable mushroom resources found in Nigeria (Pictures by Osemwegie,O.O.).

Mythological and Medicinal Mushrooms: Traditionally, mushrooms are used for nutritional, medicinal and mythological benefits in Nigeria (Alabi, 1991; Akpaja et al., 2005; Osemwegie et al., 2006). Labarere and Menini (2000) acknowledged that the uses of mushroom genetic resources are not only of high interest in agronomy, agriculture, human food and animal feed but also for the discovery, production and development of molecules or components with high added value in industries such as chemical and pharmaceutical industries. A model that shows the interaction between maximal utilization of mushroom resources that yields economic benefits and their exploration is attempted in Fig. 1. This emphasized the relative significance of field study and effective documentations as the bedrock for efficient mushroom exploitation. The nutrients and toxicological profile of edible wild mushrooms in Nigeria have been studied (Aletor, 1995; Fasidi and Kadiri, 1995). There is however dearth of information on the anti-oxidant property of edible and medicinal mushrooms indigenous to Nigeria.
The level of mushroom nutriceuticals on a global scale confirmed that mushrooms are good health food and reports abound in Nigeria on their use for the treatment of malnutrition in infants, diabetes, obesity or hyperlipidemea, sterility, anemia, mumps, fever and protein deficiency (Akpaja et al., 2005; Okhuoya and Akpaja, 2005; Idu et al., 2007). Zadrazil (1984) reported that mushrooms can also be used in improving the digestibility in ruminant animals. Recently, Ganoderma species have been successfully tested in poultry farming for the improvement of egg-laying and disease resistant capacity of birds in Nigeria (Ogbe et al., 2008). Although the locals and other folk medicine practitioners demonstrated deep knowledge of the medicinal use of mushrooms (Osemwegie, et al, 2006; Idu et al., 2007), they are however ignorant of the active principle(s) responsible for the remedy observed. This inherited knowledge has been a source of wealth and reference for practitioners. Prolific discoveries of value added products (Table 4) e.g. ergot, cordycepin, cyclosporine, griseoflvin and other antitumour, antiviral, immuno-modulator,

* Corresponding author: *Osemwegie, O.O. 
hormonal and antimicrobial products used in medicine and/or pharmacopeias elsewhere in the world are however challenging (Wainwright, 1992; Jonathan and Fasidi, 2005; Gbolagade et al., 2007). Furthermore, the 2009, $2^{\text {nd }}$ African Conference on Edible and Medicinal Mushrooms revealed that Beta-glucan based dietary supplements of mushroom origin are effective for the treatment of Buruli ulcer caused by Mycobacterium ulcerans in Ghana while Ganoderma lucidum (Leyss.) Karst. Tested in separate study for the treatment of Eimeria tenella infected broiler chickens in Nigeria (unpublished). Documentations of their uses in the treatment of both human and animal ailments and/or on the production of drugs (molecules) in Nigeria are scanty.

Many of the heresy and mythological records implicated indigenous Nigerian mushrooms in the preparation of different charms (talismans or voodoo) by traditional worshippers (personal communication). They are also symbolically used and given out to adversaries as form of warnings by the Igbo speaking people of Nigeria while the Yorubas used selected mushrooms with psychoactive and hallucinogenic effects for idol worshipping and spiritualism (Oso, 1975; Akpaja et al., 2005; Okhuoya and Akpaja, 2005). The presence of Schizophyllum or Daldinia species on dead decaying woods posit quality-burning trait or tinder by fire-wood gatherers in Nigeria. A few elders of the Edo/Delta region confirmed that Ganoderma species when brewed is good for improving libido and vitality in adults (Osemwegie et al., 2006). The $2^{\text {nd }}$ African Conference on Edible and Medicinal Mushrooms in Ghana, March 24-28, 2009, also revealed that Cordyceps and Ganoderma were being tried for treatment of alcoholism in Asia. A recent study on the ethnomycological uses of macrofungi in Edo State, South-South of Nigeria observed that Pycnoporus cinnabarinus (Fr.) Karst was used as hair-dye and lipstick by the maidens of Okomu (Osemwegie and Okhuoya, 2009). The potentials inherent in diverse mushroom-forming fungi around the globe are therefore infinite even amongst Nigerian's mushroom taxa (Fig. 2).

Nigeria by virtue of its vantage tropical location is one of the world's potential hotspots for various forms of biological resources including mushroom (Myers et al., 2000; Akpaja et al., 2003). This position is also derived from the diversity of vegetation i.e. savannah, rainforests, riparian forests and mangroves that characterized Nigeria (Osemwegie et al., 2006; Osemwegie and Okhuoya, 2009). Currently, the exploitation of indigenous Nigerian mycoresources is still overshadowed by the preponderance of green plants. Vigorous researches on these easily-overlooked forest members might evolve an accidental source of drugs that would resolve the world's cancer, AIDS and leukemia problems. The poor knowledge and documentation of mushroom uses in healthcare delivery coupled with the lack of up-to-date inventory on mushroom taxa in Nigeria impairs government efforts at developing complimentary (folk) medicine practices to the level witnessed in China and other Asian countries (Chang and Miles, 1991).

Agro-Industrial Wastes, Agriculture, Poverty Alleviation And Mycorestoration.: One of the strongest technical points recently advancing mushroom production in Nigerian besides improving food options is the conversion of ordinarily valueless or toxic wastes of diverse origin to value added products via a permaculture system. Nigeria by virtue of her population size generate several tons of agricultural, industrial, municipal and domestic wastes that overwhelms the nation's waste disposal machinery and are potentially degradable by mushrooms (Okhuoya and Okogbo, 1991; Okhuoya et al., 1998; Osemwegie et al., 2002). These wastes are tried as substrates or solid-waste substrate supplements and/or ingredients for compost in mushroom cultivation (Table 2).

Mushroom-forming fungi are gaining global popularity in both liquid fermentation of industrial effluents and many lignocellulosic wastes such as waste papers, banana and plantain leaves, and/or peelings, sawdust of different tree origin, oil palm fruit fibres, bunches and cakes, (Oei, 1991; Okhuoya and Okogbo, 1991; Okhuoya et al., 1998; Osemwegie et al., 2002;). There are huge potential socio-economic benefits associated with the effective and efficient bioconversion of agroindustrial wastes to valued edible sporocarps (Chang and Miles, 1991). The growth of mushroom production industries and the use of agro-industrial based substrate as the major raw material may provide a partial solution to the nation's waste management problems and pollution challenges, poverty and rising youth unemployment. The potential use of spent substrates in crop farming as soil conditioner and/or mycorrhization practices have also been emphasized by Labarere and Menini (2000) and Wasser (2007). Mycorrhization by spore has been successfully adopted in Congo and South Africa in Pinus agroforestry with Pisolithus tinctorius (Marx et al., 1993). Documented account in forest and/or agroforest management in Nigeria is dearth despite high incidence of mycorrhiza mushrooms (Fig. 2). To fully tap into the verse mycorrization potentials of mushrooms, it is significant to improve the nation's knowledge of mycorrhizae diversity and mycorrhizian status of many indigenous Nigerian trees via further studies. Spent substrates derived from a few small-scale mushroom cultivation farms across the country also have been poorly exploited as sources of single-cell protein, animal feeds, organic manure, soil amendments/conditioner and biofuel in Nigeria as observed in some developed nations of the world (Zadrazil, 1984; Labarere and Menini, 2000). This is attributed to inchoate mushroom production, 
accessible alternatives such as fertile lands, manure from animal dung and chemical fertilizer, annual national output of used composts and substrates coupled with a lack of technical knowledge on sustainable re-use of spent substrates in the country.

Human activities have been reported to impact negatively on arable lands contaminating them with pesticides, petroleum hydrocarbons, heavy metals and waste engine oil pollutants, and consequently causing arable land shortage and other environmental challenges. A survey of land use practice in Nigeria revealed that bush fallowing is more popular in addressing the problems of contaminated (polluted) and/or low-yield agricultural lands. This practice according to Adedokun and Ataga (2006) allows for the slow process of natural restoration or remediation. Other strategies reportedly used in recovering contaminated farmlands are capital and labour intensive and this include excavation followed by incineration and/or secured land-filling (Adedokun and Ataga, 2006). These methods currently undermine bioremediation posed varying degree of environmental problems to humans. Therefore, the replacement of bush-fallow system with bioremediation in rehabilitating polluted arable land is slowly being embraced as a faster, cheaper and more environment friendly method in Nigeria. Mushrooms through the evolution of specialized feeding habit or saprotrophism along with other plant resources have been tested in this regards. $P$. tuberregium and $P$. pulmonarius were the most widely used mushrooms in bioremediation studies in the country (Anoliefo et al., 2003; Isikhuemhen et al., 2003, Adedokun and Ataga, 2006). There is however no documentation on the use of indigenous Nigerian mushrooms biopulping and delignification process. The observation made by Okolie and Gbuji (2002) that some indigenous mushrooms recorded non-toxic level of cyanide gave credence to the bioaccumulation potential of mushrooms. Ukpebor et al. (2007) has also implicated mushrooms in cassava processing. The ex situ application of mushrooms in tackling various oil-spill and heavy metal contamination challenges in Nigeria is uncommon due to failure of field trials of laboratory results (Oghenekaro et al., 2008).

The uses of mushroom-forming fungi in Nigerian agricultural practices is still undefined in the areas of pest and disease control despite reports that Cordiceps, Gibellula, Beauveria bassiana, Leptinortarsa decenliniata, Pseudogibellula are entomogenous (Thorn and Barron, 1983). Some wood-decaying fungi occurring in Nigeria e.g. Pleurotus, Schizophyllum and Hohenbuehelaria are nematophagous - utilize the nutrient in nematodes to supplement the low level of accessible Nitrogen in their wood substrate (Robert and Hajek, 1993). Few achievements have been recorded using different species of Nigerian mushrooms as

* Corresponding author: *Osemwegie, O.O. antagonist of other harmful pathogens of both plants and animals (Table 4).

Sources of information on African mushroom germplasm collections, taxonomy of African mushroom taxa and how they have been exploited are scanty (Labarere and Menini, 2000). This lends credence to the fact that systematic documentation of mushroom diversity and conserved data will inspire maximum utilization of mycoresources in Nigeria. Data on mushrooms do not yet compare to those of plant genetic resources around the globe. Although, Nigeria actively contributed to the global plan of action on the state of the world's plant genetic resources, it is still ranked low amongst the few nations of Africa yet to place national ex situ collections under the auspices of the F.A.O and develop their own gene bank. The reason for this may be political or attributed to lack of technical knowledge and assistance in the areas of sampling, identifying and preserving mushrooms. Indigenous Nigerian mushrooms are limited to food and folk medicinal uses as well as for income through their sales in village markets. This may have been the reason why conservatively speaking, only roughly less than $20 \%$ of the potentials inherent in Nigerian mushroom genetic resources have been tapped. A well established and sustainable national mushroom culture/germplasm bank will improve accessibility to strains that can add value to the growth of industries, economy, medicines, pharmacy, environment and agriculture while encouraging mushroom researches and explorations for human benefits (Fig. 1).

Nigerian mycologists are therefore challenged to collaborate with mycological herbaria and international agencies such as the United Nations and Food and Agricultural Organization for educational, scientific and technical support in the areas of training mushroom taxonomists and improving food security. This is primordial to solving national problems associated with hunger, poverty, economic development, diseases and unemployment using mushroom-forming fungi as veritable tool.

\section{REFERENCES}

Adebayo, J.G., Banjo, N.O. and Abikoye, E.T. 2009. Evaluation of yield of oyster mushroom (Pleurotus pulmonarius) grown on cotton waste and cassava peel. African Journal of Biotechnology 8(2):215-218.

Adedokun, O.M. and Ataga, A.E. 2006. Effect of crude oil and oil products on growth of some edible mushrooms. Journal of Applied Science and Environmental Management 10(2):91-93.

Adejumo, T.O. and Awosanya, O.B. 2005. Proximate and mineral composition of four edible mushroom species from South Western 
Nigeria. African Journal of Biotechnology 4(10):1084-1088.

Akpaja, E.O., Isikhuemhen, O.S. and Okhuoya, J.A. 2003. Ethnomycology and usage of edible and medicinal mushrooms among the Igbo people of Nigeria. International Journal of Medicinal Mushrooms 5:313-319.

Akpaja, E.O., Okhuoya, J.A. and Eliwer Heferere, B.A. 2005. Ethnomycology and indigenous uses of mushrooms among the Bini-speaking people of Nigeria: A case study of Aihuobabekun community near Benin City, Nigeria. International Journal of Medicinal Mushroom 7(3): 373-374.

Alabi, R.O. 1991. Mycology and Nigerian culture: past, present and future. Proceedings of $1^{\text {st }}$ Conference on African Mycology; Mauritius, June 10-15, 1990. pp. 43-52.

Alemawor, F., Dzogbefia, P.V., Oddoye, K.O.E. and Oldham, H.J. 2009. Effect of Pleurotus osteatus fermentation on cocoa pod husk composition: Influence of fermentation period and $\mathrm{Mn} 2+$ supplementation on the fermentation process. African Journal of Biotechnology 8(9):1950-1958.

Aletor, V.A. 1995. Compositional studies on edible tropical species of mushrooms. Food Chemistry 54:265-268.

Aletor, V.A. and Aladetimi, O.O. 1995. Compositional studies on edible tropical species of mushrooms. Food Chemistry 54:265-268.

Ayodele, M.S. and Okhuoya, A.J. 2007. Cultivation studies on Psathyrella atrounmbonata Pegler a Nigerian edible mushroom on different agro-industrial wastes. International Journal of Botany 3(4):394-397.

Anoliefo, G.O., Isikhuemhen, O.S., Ohimain, E. 2003. Phytoassesment of soil polluted with Forcados blend crude oil exposed to a whiterot fungus, Pleurotus tuberregium (Fr.) Sing. Proceedings of the National Conference on Environmental Science and Technology. 8 -9 September, 2002, Greensboro. pp. 43-59.

Badalyan, S., Isikhuemhen, O.S. and Gharibyan, G.M. 2008. Antagonistic/antifungal activities of medicinal mushrooms Pleurotus tuberregium (Fr.) Singer (Agaricomycetideae) against selected filamentous fungi. International Journal of Medicinal Mushrooms 10:155-162.
Chang, S.T. and Miles, P.G. 1991. Recent trends in world production of cultivated edible mushrooms. The Mushroom Journal 503: 1518.

Ene-Obong, H.N. and Camovale, E. 1992. Nigerian soup condiments: traditional processing and potential as dietary fibre sources. Food Chemistry 43:29-34.

Fasidi, I.O. and Kadiri, M. 1993. Use of agricultural wastes for the cultivation of Lentinus subnudus (Polyporales, Polyporaceae) in Nigeria. Revista de Biologia Tropical 41:411-415.

Fasidi, I.O. and Kadiri, M. 1995. Toxicological screening of seven Nigerian Mushrooms. Food Chemistry 52:419-422.

Fasola, R.T., Golagade, S.J. and Fasidi, O.I. 2007. Nutritional requirements of Volvariella speciosa (Fr. ex Fr.) Singer, a Nigerian edible mushroom. Food Chemistry 100:904-908.

Flegg, P.B. 1992. Future strategies for mushroom production. Mushroom Research 1:13-18.

Jonathan, S.G and Fasidi, I.O. 2005. Antimicrobial activities of some selected Nigerian mushrooms. African Journal of Biomedical Research 8(2):83-87.

Gbolagade, S.J. 2006. Bacteria associated with compost used for cultivation of Nigerian edible mushrooms Pleurotus tuber-regium (Fr.) Singer and Lentinus squarrosulus Berk. African Journal of Biotechnology 5: 338-342.

Gbolagade, J.S., Ajayi, A., Oku, I. and Wankasi, D. 2006. Nutritive value of common wild edible mushrooms from southern Nigeria. Global Journal of Biotechnology and Biochemistry 1(1):16-21.

Gbolagade, J.S., Kigigha, L. and Ohimai, E. 2007. Antagonistic effect of extracts of some Nigerian higher fungi against selected pathogenic microorganisms. AmericanEurasian Journal of Agriculture, Environment and Science 2(4):364-368.

Ibekwe, I.V., Azubuike, I.P., Ezeji, E.U. and Chinakwe, C.E. 2008. Effect of nutrient sources and environmental factors on the cultivation and yield of oystermushroom (Pleurotus ostreatus). Pakistan Journal of Nutrition 7:349-351.

Idu, M., Osemwegie, O., Timothy, O. and Onyibe, H.I. 2007. A survey of plants used in 
traditional healthcare by Waja tribe Bauchi State, Nigeria. Plant Archives 7(2): 535-538.

Isikhuemhen, O.S., Anoliefo, G.O. and Oghale, O.I. 2003. Bioremediation of crude oil polluted soil by white rot fungus, Pleurotus tuberregium (Fr.) Sing. Environmental Science and Pollution Research 10:108-112.

Jumpponen, A., Claridge, W.A., Trappe, M.J., Lebel, T. and Claridge, I.D. 2004. Ecological relationships among hypogeous fungi and trees: inferences from association analysis integrated with Habitat modeling. Mycologia 96(3):510-525.

Labarère, J and G. U. Menini. 2000. Collection, Characterization, Conservation and utilization of mushrooms, germplasm resources in Africa. In: The Proceedings of the First International Congress for the Characterization, Conservation, Evaluation and Utilization of Mushroom Genetic Resources for Food and Agriculture. FAO, Bordeaux, France; 9-13, March, 1998.

Marx, D.H., Maul, S.B. and Cordell, C.E. 1993. Application of specific ectomycorrhizal fungi I world forestry. In: Leatham,G.F. (ed.). Frontiers in industrial mycology. Chapman \& Hall, New York. pp.78-98.

Kadiri, M. and Fasidi, I.O. 1992. Secondary plant products in some Nigerian mushrooms. Nigerian Journal of Botany 5: 187-192.

Morris B. 1990. An annotated check-list of the macrofungi of Malawi. Kirkia 13:323-328.

Myers, N., Mittermeier, G.C., Da Fonseca, B.A.G. and Kent, J. 2000. Biodiversity hotspots for conservation priorities. Nature 403(24):853 858 .

Oei, P. 1991. Some aspects of mushroom cultivation in developing countries. Mushroom Sciences 13:777-780.

Ogbe, A.O., Mgbojikwe, L.O., Owoade, A.A., Atawodi, S.E and Abdu, A. P. 2008. The effect of wild mushrooms (Ganoderma lucidum) supplementation of feed on the immune response of pullet chickens to infectious bursal disease vaccine. Electronic Journal of Environmental, Agricultural and Food Chemistry 7(4): 2844-2855.

Oghenekaro, O.A., Okhuoya, A.J. and Akpaja, E.O. 2008. Growth of Pleurotus teberregium (Fr.) Singer on some heavy metalsupplemented substrates. African Journal of Microbiology Research 12: 268-271.
Ogundana, S.K. 1975. Nigeria and the mushrooms. Mushroom Science 10(2): 537-545.

Ogundana, S.K. and Fagada, O.E. 1982. Nutritive value of some Nigerian mushrooms. Food Chemistry 8:263-268.

Okhuoya, J.A. and Okogbo, F.O. 1991. Cultivation of Pleurotus tuber-regium (Fr.) Sing. on various farm wastes. Proceedings of Oklahoma Academy of Science 71:1-3.

Okhuoya, J.A. 1997. Mushroom cultivation: the Nigerian experience. In: Dirar,A, editor. Food processing technologies for Africa-emerging technologies series. UNIDO. pp 153-168.

Okhuoya, A.J., Eboigbe, O.E. and Isikhuemhen, O.S. 1996. Growth interactions between Pleurotus tuberregium (Fr.) Sing and Sclerotium rolfsii Saac, in the laboratory. Folia Microbiologia 41:433-435.

Okhuoya, J.A. and Akpaja, E.O. 2005. Mycomedicine and Ethnomycology: The Nigerian Experience. International Journal of Medicinal Mushrooms 7(3): 439-440.

Okhuoya, A.J., Isikhuemhen, O.S. and Evue, G.A. 1998. Pleurotus tuberregium (Fr.) Sing. The sclerotia and sporophore yield during cultivation on sawdust of different woody plants. International Journal of Mushroom Science 2:41-46.

Okolie, P.N. and Gbuji, A.D. 2002. Cyanide profiles of some Nigerian edible mushrooms in raw and processed states. Journal of Medicine and Biomedical Research 1(2):60-64.

Onuoha, I.C., Ukaulor, U. and Onuoha, C.B. 2009. Cultivation of Pleurotus pulmonarius (mushroom) using some agrowaste materials. Agricultural Journal 4:109-112.

Osemwegie, O.O., Isikhuemhen, O.S., Onyolu, O.J. and Okhuoya, A.J. 2002. Cultivation of a selected sporophore-only-producing strain of the edible and medicinal mushroom, Pleurotus tuberregium (Fr.) Singer (Agaricomycetideae) on waste paper and plantain peelings. International Journal of Medicinal Mushrooms 4: 343-348.

Osemwegie, O.O., E.G.Eriyaremu and J. Abdulmalik. 2006. A survey of macrofungi in Edo/Delta region of Nigeria, their morphology and uses. Global Journal of Pure and Applied Science 12(2):149-157.

Osemwegie, O.O and Okhuoya, A.J. 2009. Diversity of macrofungi in oil palm agroforests

* Corresponding author: *Osemwegie, O.O. 
of Edo State, Nigeria. Journal of Biological Sciences 9(6):584-593.

Oso, B.A. 1975. Mushrooms and the Yoruba people of Nigeria. Mycologia 67(2):311-319.

Oso, B.A. 1977. Pleurotus tuberregium from Nigeria. Mycologia 69: 271-279.

Roberts, D and Hajek, M. 1993. Entomopathogenic fungi as bioinsecticides. In: Leatham,G.F. (ed.), Frontiers in industrial mycology. Chapman and Hall, New York. pp 144-159.

Ukoima, N.H., Ogbonnaya, O.L., Arikpo, E.G. and Ikpe, N.F. 2009. Cultivation of mushroom (Volvariella volvacea) on various farm wastes in Obubra Local Government of Cross River State, Nigeria. Pakistan Journal of Nutrition 8:1059-1061.

Ukpebor, J.E., Akpaja, E.O., Ukpebor, E.E., Egharevba, O. and Efedue, E. 2007. Effect of the edible mushroom, Pleurotus tuberregium on the cyanide level and nutritional contents of rubber seed cake. Pakistan Journal of Nutrition 6(6): 534-537.

Wainwright M. 1992. An Introduction to fungal biotechnology. John Wiley and Sons Ltd, England. 202p.

Wasser, P.S. 2007. A book review; mycelium running: how mushrooms can help save the world. Herbalgram 76: 50-57.

Yongabi, K., Agho, M and Martinez-Carrera, D. 2004. Ethnomycological studies on wild mushrooms in Cameroon, Central Africa. Micologia Aplicada International 16:34-36.

Zadrazil, F. 1984. Microbial conversion of lignocellulose into fees. In: Sundtal S. and Owen E, editors. Development in animal and veterinary sciences. Elsevier Science Publishers, Amsterdam.

Zoberi, M.H. 1973. Some edible mushrooms from Nigeria. Nigerian Field 38:81-90. 